\title{
Fermentation: A Green Herbal Extraction Process for Polyphenols
}

\author{
Prerna and Aeri Vidhu* \\ Department of Pharmacognosy and Phytochemistry, School of Pharmaceutical Education and Research, India \\ *Corresponding author: Aeri Vidhu, Department of Pharmacognosy and Phytochemistry, School of Pharmaceutical \\ Education and Research, Jamia Hamdard (Deemed to be University), New Delhi-110062, India
}

\begin{tabular}{|c|c|}
\hline ARTICLE INFO & ABSTRACT \\
\hline Received: October 28, 2020 & Citation: Prerna and Aeri Vidhu. Fermentation: A Green Herbal Extraction Process for \\
\hline Published: 㹃 November 05, 2020 & Polyphenols. Biomed J Sci \& Tech Res 31(4)-2020. BJSTR. MS.ID.005137. \\
\hline
\end{tabular}

\section{Opinion}

Fermentation is one amongst the herbal extraction process that undergoes enzymatic degradation of plant cell wall, followed by maceration thus better leaching of plant secondary metabolites from the matrix, without the application of high heat, ultra sonic wave and other radiation sources for extraction which usually degrades a number of bioactive constituents especially phenols. The extraction of plant polyphenols can be done through various methods including cold pressing, supercritical fluid extraction and organic solvent extraction, ultrasound-assisted extraction and microwave-assisted extraction however the techniques have disadvantages in low extraction yield in case of bound phenolics. In this regard fermentation had came up as effective extraction method that removes undesirable toxins, release bound phenolics and convert various phenolic compounds into different metabolites, such as deglucosides, sulfoconjugates and glucuronides through phase I/II metabolism. Usually most of the secondary metabolites are linked to the plant cell wall through a hydroxyl $(\mathrm{OH})$ or carbon-carbon bonds (C-C) linkage therefore an additional step of hydrolysis is required in case all other extractions except fermentation. For hydrolysis, either acid or alkaline chemical pre treatments or fermentative enzymatic treatments are performed to maximize extractive yield however former resulted into unwanted transformations and toxic effects on environment due to use of chemicals.

Also, different extraction methods involves use of chemical solvents varying usually ethanol, ethyl acetate chloroform, petroleum ether, n-hexane etc., based on polarity are more or less harmful to human intake, however for fermentation mostly aqueous (water) solvent is required. A gradient of successively

produced alcohol or acids during the fermentation, helps in better extraction of active compounds as no additional chemical solvents has been added from outside. Therefore, fermentation has been regarded as environmental safe technique over other extraction methods. Also, fermentation process removes undesirable sugars from herbal material leading to enhanced bioavailability of the formulation. Along with enhancement of the bioavailability of present secondary metabolites, the microorganisms play an important role in fermentation as probiotics. As they follow a large microbial conversion pathways leading to bioconversion of plant constituents thus enhancing the functional features of medicinal plants and diminishing toxic side effects. Various enzymes produced by different micro-species (bacteria, fungi, yeast) for the degradation of cell matrix plays important role as fermentation initiators producing specific byproducts.

\section{Ayurvedic Fermented Biomedicines}

Ayurveda is one of the Indian traditional systems of medicine, that employs vast use of single as well polyherbal drugs and formulations documented in various Ayurvedic classics and Ayurvedic Formulary of India (AFI) [1,2]. These formulations involve transfer of active constituents of herbs in menstrum by different extraction processes of which 'Sandhana kalpana' (Asava and aristha) is a unique dosage form of Ayurveda which involves fermentation [3]. Sandhana kalpana are biomedical fermented formulations, in which menstrum (decoction or juice), Sugar source (Jaggery or honey), Prakshepa dravyas (fine powder of aromatic/spicy herbs) and fermentation initiators ie., woodfordia and madhuka flowers) are mixed in an inert vessel, sealed and kept for specific time period to facilitate fermentation process. These 
are weak medicated wines prepared by anaerobic fermentation of herbal decoction or juices, known for their digestive and cardiotonic action [2]. They are prepared through controlled fermentation thus moderately alcoholic (limit of $5-10 \%$ by volume), sweetish with slightly acidic and aromatic in flavor, making the formulation palatable. These formulations are much stable being exposed to a low concentration of alcohol. Since it contains alcohol which itself is a known preservative, it helps in maintaining longer shelf life, by protecting from any microbial attack.

Since during its processing, the menstrum undergoes a gradient of rising alcohol level, it extracts a wide range of active ingredients thus improving the extraction from herbs comparable to other Ayurvedic medicines [2].These aqueous-alcoholic preparations are superior to tinctures for better absorption in gut being partly digested. The generated alcohol serve as dual actor as preservative and solvent medium for better extraction of active principles from the ingredients present hence, they have longer shelf life. Ethanol fermentation is an ancient process to prepare alcoholic beverages by use of yeast. In these Ayurvedic Biomedicines, fermentation is brought by addition of external sugar source however natural fermentative agents (usually herbs like Woodfordia fruticosa and Madhuca longifolia flowers) are used for initiating fermentation thus avoiding external source of yeast. The Ayurvedic Formulary of India is published by Department of AYUSH, Government of India, detail the manufacturing process of 57 fermented formulations along with ingredients (with their part used) and specific composition [2]. In view of the present need for the standardization of herbal based formulations, our lab is undertaking the marker based scientific validation of Aristas and Asavas to substantiate the basic philosophy of Ayurveda [4-7].

\section{References}

1. (2000) Anonymous. Ayurvedic Pharmacopoeia of India. Volume 1, Controller of Publication, Ministry of Health and Family Welfare, Govt. of India p. 15-16.

2. (2003) Anonymous. The Ayurvedic Formulary of India, Government of India, Part-I-III, (2 ${ }^{\text {nd }}$ Edn., $)$. Ministry of health and family welfare, Department of Indian system of medicine and Homoeopathy, New Delhi, India.

3. Shrivastava S (1998) Sarangadhara Samhita, Chaukhamba Orientalia, Varanasi, India.

4. Mishra S, Aeri V (2015) A Comparative study of prepared and marketed Asokarista with respect to physicochemical parameters and phytochemical markers. Int J Pharmacog Phytochem Res 7(1): 144-149.

5. Mishra S, Aeri V (2015) Evaluation of pre and post-fermented aqueous decoction of Saraca asoca by High-Performance Thin-Layer Chromatography. J Planar Chromatography 28(1): 36-41.

6. Mishra S, Aeri V (2017) Biotransformation of lignan glycoside to its aglycone by Woodfordia fruticosa flowers: Quantification of compounds using a validated HPTLC method. Pharm Biol 55(1): 360-366.

7. Prerna, Aeri V (2020) Physicochemical and marker based optimization of fermentation process of Drakshasava, an Ayurvedic polyherbal formulation. Ind J Tradit Know 19(1): 120-127.
ISSN: 2574-1241

DOI: 10.26717/BJSTR.2020.31.005137

Azhar Equbal. Biomed J Sci \& Tech Res

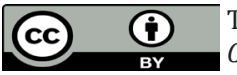

This work is licensed under Creative Commons Attribution 4.0 License

Submission Link: https://biomedres.us/submit-manuscript.php

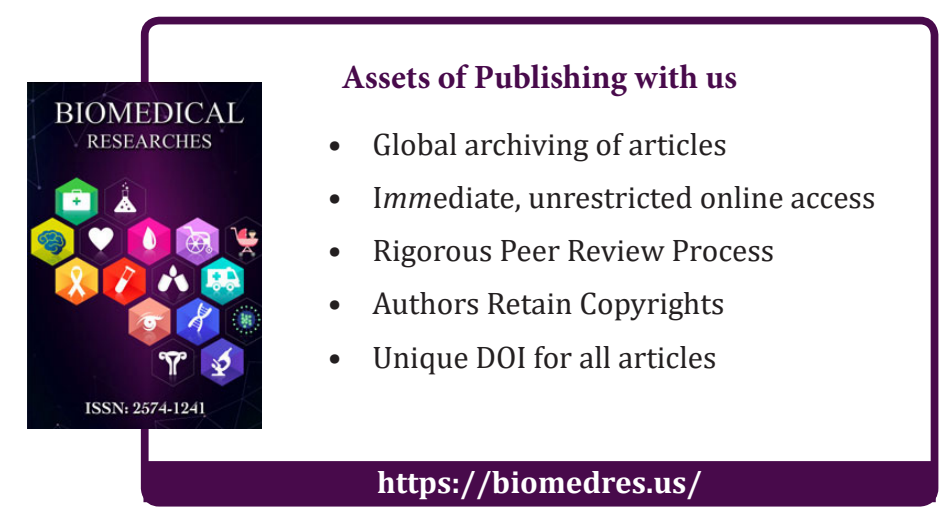

